\title{
Gaelic Art Culture (Continued)
}

Author(s): Mario

Source: All Ireland Review, Vol. 3, No. 16 (Jun. 21, 1902), pp. 248-249

Published by: All Ireland Review

Stable URL: http://www.jstor.org/stable/20546116

Accessed: 15-06-2016 06:33 UTC

Your use of the JSTOR archive indicates your acceptance of the Terms \& Conditions of Use, available at

http://about.jstor.org/terms

JSTOR is a not-for-profit service that helps scholars, researchers, and students discover, use, and build upon a wide range of content in a trusted

digital archive. We use information technology and tools to increase productivity and facilitate new forms of scholarship. For more information about JSTOR, please contact support@jstor.org.

All Ireland Review is collaborating with JSTOR to digitize, preserve and extend access to All Ireland Review 
NESSA.

By L. H'Manus.

Author of "Lally of the Brigade," "The Silk of the Kine."

(The scene of this story is laid in Ireland, in the time of the English Commonwealth, 1654.)

\section{CHAPTER VI.}

The soldiers had fallen in on the yard, each man with a lash. They knew that they were to be marched down to the neadow, and there execute the sentence on Belk. The morning was grey and still, and the wild birds screamed on the marsh. The men had disciplined their faces into a look of impassivity. It was known that the woman had escaped, and the scene had thus lost its dramatic element. The provostmarshal approached the keep, and a few minutes later loud and angry voices came from the building.

The news spread at once. The men swayed in their ranks and talked loudly. Presently the provost-marshal and his men appeared, with reddened, gloomy faces. A minute later Hewson and the cornet came into the yard.

"The prisoner hath escaped, sirs," the provostmarshal reported. "The bolt was secured, and the sentinel saw no man approach."

"Where is the captain?" said Hewson. Walcot was already in the yard. $\mathrm{He}$ had followed his two officers, and called the guard toward him. He listened to the report with calmness.

"Arrest the sentry!" he ordered, "and let three search parties be sent out at once." He walked forward and stood before the troop. His eyes fell on Sibb's face. 'The sergeant was purple with wrath.

"Men," said Walcot, "the prisoner hath escaped. He cannot be far, and the patrols will overtake him. His punishment is but delayed."

Sibb stood forth. There was a dull flame in his eyes. "Sir, with your leave, I will utter" that that is on my mind," he said. "There hath been an accomplice in this matter, and I would urge that there be a casting of lots after a solemn prayer."

Walcot's nostrils widened; then he looked straight before him. "I believe in the honour of my troop," he answered, "therefore no lot shall be cast."

A hoarse cheer broke from the soldiers, Walcot stood still, his head held high. When there was silence again in the ranks he turned to Hewson, who had drawn near. "March the men down to the meadows, Lieutenant," he commanded, and walked back to the keep.
Later in the day the three officers met in Walcot's room, and talked gravely about Belk's escape. The cornet alone spoke with an open mind. In his heart he was rather glad that the trooper had escaped the lash, and he ventured to say as much. Hewson reproved him, and to say as much. Hewson reproved him, and Walcot, after making a few 'remarks, spoke of other matters.

Two weeks followed, but Belk was not caught. Walcot questioned each patrol on its return. The men rode east, and north, and south, but did not carry the search to the west. Sibb came in despair to his captain. "Sir," he pleaded, "let a watch be set on the house of Treena-Cresha; for the woman may return thither, and where she is will Belk be found."

"Let the watch be set," said Walcot, and dismissed the sergeant. Sibb in his zeal deter mined to watch the house himself, and set out with two men, having first summoned the troop to prayer, and urged the culprit to confess.

As to Walcot, he rode often from the castle, and the men believed that he went to his grant. $\mathrm{He}$ dare not cross the ford before their eyes, but after riding east would turn and strike the river near its confluence with the Geesthan At times he sat in his own room with his face buried in his hands. At these moments he did not pray. He scorned to plead for pardon for the sin he had committed, and still loved, $\mathrm{He}$ had given himself to the devil-he was a liar and undone. The abyss was at his feet-he sought to forget how near. Once the cornet, opening the door, found him thus, and Walcot had looked up with a black face, and an oath on his lips. Then his eyes had cleared; he rose to his feet, and smiled, and placed the fine of twelvepence in the bag kept for such charges. The cornet had gone away full of ad-miration for his rectitude.

On the second day after Belk's escape Walcot had been rowed across the lake to the tower. Hobbs, with his eyes on the water, sat in the bows. That morning Tadhg had rowed to the mainland by the mountains, and had brought back an ancient man. When Hobbs left the room in which he had married Walcot to Nessa, this old man passed him in the doorway. Later on in the afternoon Tadhg took the priest back to the shore.

The tower was square, and had once had four stories. It filled the whole space of the island except in one point. This was where a neck of rock jutted into the iake. A few dwarf oaks grew on the light soil, and those who came to the island landed at this place. The neck was divided into tiny bays, in each of which a boat could lie.

(To be continued.)
GAELIC ART CUL'TURE.-Continued.

It would be scarcely wise, however, as some would suggest, to launch out a new society for this purpose. Unfortunately, the condition of Irish Art to-day is no better than that of the Irish Language not very long since, and one must therefore act prudently but progres-
sively. We must take things as they are and develop them as rapidly as possible, but on sure, solid lines. As with the language, we must to a large extent begin in the schools, teaching the children of Ireland that Ireland is beautiful, and the way they can best beautify the things around and about them. We must endeavour to illustrate in a suitable style the books used in the schools: the books of our ancient and modern literature; we must have pictures to remind us of our history and to encourage us to study our history; we must make it easy for our dramatists to stage their plays by fostering a taste for artistic scenery and national dress ; we must display in the stained windows of our churches, schools, and public halls
sing incidents in the evolution of our race; in a word we must develop a school of art in every branch of a kind that looking round us we may say proudly and deservedly, " this is my own, my native land"

For the present, at least, it would be sufficient to add some ten to fifteen competitions to the programme of the Oireachtas. As already explained a large proportion of these would be complementary. There is a prize offered each year for an Irish Drama; for essays and poems on historical subjects, \&c.- Themes that would readily lend themselves to artistic treatment. Then, again, our concert proyrammes, our Christmas cards, our St. Patrick's Feast cards; our Xmas almanacs; our business circulars, \&c., are things, though trival in themselves, yet most important in the development of our individuality and independent nationhood. Remembering that it was through these very trivialities that we have been so thoroughly Anglicised. There is no one cure for our present condition. We have drifted so long and so far, that if we would regain a sense of Nationality, we should adopt not one but many cures. Our music, our language, our industries, all want development. Our art, the bond of union of these separate entities, also wants development.

For some reason or other we do not read as much of any kind of literature as we should. But Art, in any country, if properly controlled, forms, as it were, a literature in itself, teaching and instructing us in those things which it is useful for us to know without any special effort on our part. This is important, for our lives are becoming more toilsome every day, leaving us less leisure and less taste for study. We in Ireland, owing to the vicissitudes in our history, have very special need for this "knowledge by suggestion." 
Moreover,allowing all other things to be favourable, the time is especially opportune for an art movement in Ireland, Contemporary art, in its effort after originality, has grown quite grotesque and degenerate in all its forms. We in Ireland have the artistic sense in plenty. With a little care and a little culture it may be that the Gael can be brought, in a short time, to show the way in the realms of art as he already does in the scientific, the literary and the political institutions of the world-

Let statue, picture, park and hall

Ballad, flag, and festival

The past restore, the day adorn

And make each morrow a new morn.

"Mario."

[Dear Mario, a very timely bit of writing this, and worthy of much attention. Gaelic was killed in Ireland through its unpleasing and unbeautiful associations. Its revival will be rapid when all the associations become again beautiful and alluring. To begin with, might I suggest that Gaelic class rooms should be as clean as spring water, and thereafter as bright and pleasant to the eye as the genius of the members can make them? -ED.]

The Cooleen is, I think, beautifully Irish. It has an indefinable, indescribable charm, a charm which proclaims it as Hibernian exceedingly, and very, very racy of the soil. I read it out lately for a small boy, who remarked strongly upon the indelicacy of Captain Power's behaviour as described in the last verse. I think that without my knowledge he had enrolled himself as one of the Cooleen's many admirers.

Is it not curious that while the poem is only half serious, the air of the Cooleen should be one of the wildest, saddest, and weirdest in the world.

\section{an čûthionn.}

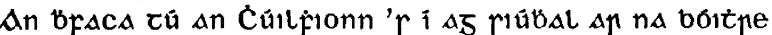
maioin seal opúcea 'r san rmüic ap a brósa? 1r romóa ósánać rúli-slar as tnúc le n-a póráó, ace ni bfásató riao mo pún-ra ap án jcúnzar ir oós leo.

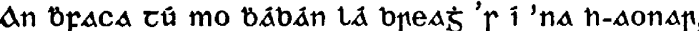
a cúl oualać omirleanać so rlınneăn rior léite, mil ap an óg-bean, 'r fior breaś 'na n-euoan, 'S ir oós le sać rpprorán sur leanán leir féin 1.

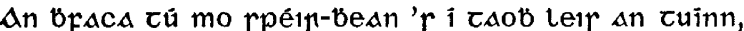
Fäıní ôn ap a meupaib ' $r$ i a' péróceać a cínn, ir é oubalic an paopac 'bi 'na maop ap an luins

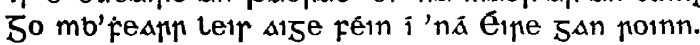

\section{[Translation.]}

\section{THE COOLEEN.}

Whether have you seen the Cooleen and she walking on the roads

On a fine dewy morn and not a speck on her shoes?

Many is the grey-eyed youth envious to marry her,

But they shall not get my loved one, think how they may.

Have you seen my darling one on a fine day by herself, Her ringletty hair flowing down to her ankles?

Honey (attractiveness) on the young woman and a beautiful rose in her face,

And every upstart imagines that she with himself is a follower (sweetheart).

Have you seen my queenly woman and she beside the wave,

Golden rings on her fingers, and she combing her hair (head).

It is what the Power said, who was in his mayoralty of the ship,

That he would rather have her to himself than all Ireland (without division).
SUGGESTIONS HOW TO INCREASE THE NUMBER OF SOUND AGRICULTURAL HOLDINGS AND TO IMPROVE THE LOT OF LABOURERS.

\section{By A. Crichton.}

(Continued).

It is easy, however, to criticise. If legislation in the past has been bad for landlords, it has not been so owing to a want of criticism on their part, but rather to a deplorable want of sympathy with the cause of the tenants. So now, the war against grazing ranches, if not directed partially, at least, by those interested in grazing lands, will lead to consequences that will certainly be injurious to graziers, and also, I think, be less beneficial for all Ireland than they might be if the interests of all in Ireland were fairly considered.

I depend partly on grazing lands. I have, therefore, I think, a right to express my ideas. It is only natural that I should consider my suggestions to be honest, workable, and beneficial. I will, therefore, not waste time in describing what should be the definite object of any proposed legislation. Let the reader decide if my proposals are likely to benefit or injure the cause of all Ireland. Should they prove to be antagonistic to an all Ireland union of hope, and of working together, I shall gladly denounce them myself. Meanwhile allow me to explain suggestions which I must make more definite than I should do, perhaps, so as to make their purport clearly understood.

There are three classes that I should like to see benefited: 1st - Tenants on inadequate holdings.

2nd-Labourers in constant employment to landlords and others, as also their employers.

3rd -Labourers with irregular employment.

As a landlord myself I cannot agree to any scheme of forcible possession of land, but as a considerable portion of my income is derived from grazing cattle, I do not object to a forcible contribution on my grazing lands for the privilege of holding them in peace and contentment and good conscience. I, therefore, propose that every one in Ireland shall be subjected to a tax of $8 \mathrm{~d}$. in the pound on the valuation for all land over $£ 50$ of valuation.

The valuation of farms of over $£ 50$ valuation amounts to $\mathfrak{f} 4,898,833$.

There are 40,783 such farms.

If we, therefore, allow every man to hold $£ 50$ worth of land free from the proposed tax, we must deduct $£ 2,039,150$ from the total just quoted.

That leaves $£ 2,859,683$ as the amount on which such a tax could be levied. But the estimates quoted do not give the full results; I have, for instance, four farms in my occupation; I would, therefore, according to my proposal, be entitled to hold $£ 50$ worth of land free from special tax instead of $£ 200$, as would be the case if each farm were held by someone different. Allowing, therefore, for the very many cases of individuals holding several farms in different parts of the country, and of also the many cases where several small farms would jointly exceed $£ 50$ in valuation, it does not seem unreasonable to suppose that the total amount on which a gross tax could be made to pay would be $£ 3,600,000$, instead of $£ 2,859,683 ; 8 \mathrm{~d}$. in the $£ 1$ on $£ 3,600,000$ would bring in $£ 120,000$ per annum. I, therefore, propose that $£ 60,000$ be spent yearly by the Department of Agriculture to help those with an inadequate supply of land to obtain more land labourers in irregular employment to share under certain conditions in the boon. I also propose that $£ 60,000$ be given to employers of labour for the benefit of their labourers.

$$
\text { (To be continued.) }
$$

\section{FINN'S MEN.}

We; the Fianna of Erin, never lied;

Falsehood was never ckarged against us ; By courage and the strength of our hands We used to come out of every difficulty.

\section{SUPPORT}

IRISH

INDUSTRIES
ANTO PUTROIXASE DONEGAL CARPETS.

anisis
All particulars to be obtalned from the Agents-

MILLAR \& BEATTY, Lțd, 14 Grafton St., 56 Dawson St. 